\title{
STUDI KONTRAKSI TUGAS DAN FUNGSI HAKIM DI PENGADILAN AGAMA
}

\author{
Syaiful Hidayat \\ Institut Agama Islam Bani Fattah Jombang, Indonesia \\ E-mail: alaminilman313@gmail.com
}

\begin{abstract}
A Judge is a key element in the trial. In fact he was identical to the court itself. Similarly, the decision of the court identified with the judge's decision. Therefore, law enforcement and justice lies in the ability of judges in formulating decisions that reflect fairness. With regard to the duties and functions of the judge, in this case the trial judge Religion in Indonesia, which is one element of the law enforcement component directly involved with the legal process will be faced with a dilemma problem. On the one hand, the religious court judge must hold to Irish law. While on the other hand, the religious court judges must take into account the level of public awareness of the legal instruments. In addition, for the assurance of the process of law enforcement, religious court judges are also faced with a problem that dilemma. Because of the involvement of the religious court judges against one of the instruments carried to excess can lead to deviations of the purposes of the law itself, which is "justice".
\end{abstract}

Keywords: Judge, Religion Court 


\section{Pendahuluan}

Indonesia yang termasuk negara yang sedang berkembang, mengawali kehidupannya dengan hasrat yang kuat untuk melaksanakan pembangunan. Yang pada dasarnya, pembangunan adalah kehendak untuk melakukan perubahan terhadap situasi kehidupan yang lebih baik, membina agar lebih maju dan memperbaiki agar lebih teratur.

Pembangunan, sebagaimana di konsepsikan di atas, mengisyaratkan adanya perubahan terhadap dasar-dasar kemasyarakatan, baik bersifat struktural maupun kultural. Dasar-dasar kemasyarakatan tersebut, menurut Soerjono Seokanto ${ }^{1}$, paling sedikit mencakup: (1) agama, (2) filsafat, (3) ideologi, (4) ilmu pengetahuan, dan (5) teknologi. Dari lima aspek dasar tersebut tidak akan tercapai jika suatu masyarakat tidak mempunya dasar dan atau tata cara pelaksanaan hukum yang baik. Dengan demikian, pembangunan Hukum di Indonesia dapat di rumuskan sebagai berikut:

Pertama, Penjabaran Hukum ke dalam Sistem Hukum Indonesia. Kedua, Penciptaan serta menyusun kembali lembaga-lembaga hukum baru. Ketiga, Mengupayakan tentang bagaimana hukum tadi dapat di jalankan dengan efektif. ${ }^{2}$

Sifat khas permasalahan di bidang hukum tersebut terletak pada upaya pemetaan kembali sistem hukum, baik dalam seginya sebagai suatu struktur logis hukum maupun dalam seginya sebagai suatu sarana bagi perencanaan masyarakat ideal.

Sesuai dengan perumusan masalah di atas, maka upaya pembangunan Hukum akan melibatkan tiga komponen yang mesti di perhitungkan dengan matang dan cermat, biasa dikenal dengan istilah "Tri Darma Hukum", yaitu: (1) komponen perangkat hukum, (2) komponen penegak hukum, dan (3) komponen kesadaran hukum. ${ }^{3}$

Perangkat hukum, secara intrinsik, merupakan refleksi pembuatnya, yaitu mereka yang mempunyai peluang untuk melaksanakan serta mengawasi kekuasaan Sebab perangkat hukum, sampai tingkat tertentu, di kondisikan oleh situasi politik yang berlaku. Dengan kata lain, sebagaimana yang di ungkapkan oleh Daniel S. Lev, ${ }^{4}$ tergantung dari

\footnotetext{
1 Soerjono Soekanto, "Ilmu-ilmu Hukum dan Pembangunan Hukum", Analisis Pendidikan. No.02, Tahun ke-IV (1983), 37

2 Deden Effendi, Kompleksitas Hakim Pengadilan Agama, Jakarta: Departemen Agama R.I., 1985), 2.

${ }^{3}$ Ibid.

${ }^{4}$ DanieS. Lev, Peradilan Agama di Indonesia: Studi tentang Landasan Politik Lembaga-Lembaga Hukum, terj. H. Zaini Ahmad Noeh, (Jakarta: PT Intermasa, 1980), 16.
} 
kekuatan dan kekuasaan politik, sedangkan kondisi itu sebaliknya di tentukan oleh berbagai kekuatan lainnya, seperti sosial, ekonomi, budaya dan lain sebagainya.

Berkenaan dengan ini, maka Hakim Pengadilan Agama di Indonesia yang terlibat secara langsung dengan proses hukum, akan berhadapan dengan suatu persoalan. Di satu sisi, Hakim Pengadilan Agama harus memegang teguh tugas dan fungsi hukum yang berlaku dan diberlakukan. Sedangkan di sisi lain, harus memperhitungkan tingkat kesadaran masyarakat terhadap fungsi dan tugas hukum tersebut.

Dalam persoalan tersebut jelas, jika hukum di artikan sebagai produk atau hasil aktual dari praktek sehari-hari para pejabat hukum, bukan Peraturan-peraturan atau perundang-undangan. ${ }^{6}$ Meskipun demikian, perangkat hukum tetap dipergunakan. Paling tidak, sebagai pegangan dalam melukiskan proses sesungguhnya dari pembangunan hukum.

\section{Pengertian Hakim}

Hakim berasal dari kata hakama-yabkumu-hâkimun sama artinya dengan qâdi yang berasal dari kata qadâ-yaq.dî-qâdin artinya memutus. Sedangkan menurut bahasa adalah orang yang bijaksana atau orang yang memutuskan perkara dan menetapkannya. ${ }^{7}$ Adapun pengertian menurut syar'a yaitu orang yang di angkat oleh kepala Negara untuk menjadi hakim dalam menyelesaikan gugatan, perselisihan-perselsihan dalam bidang hukum pidana maupun perdata oleh karena penguasa sendiri tidak dapat menyelesaikan tugas peradilan. ${ }^{8}$ Hakim sendiri adalah pejabat peradilan Negara yang diberi wewenang oleh undang-undang untuk mengadili.

Sedangkan dalam undang-undang kekuasaan kehakiman adalah penegak hukum dan keadilan yang wajib menggali, mengikuti dan memahami nilai-nilai hukum yang hidup di masyarakat.

\footnotetext{
5 Soerjono Soekanto, "Ilmu-ilmu......., 40.

${ }^{6}$ Daniel S. Lev, Peradilan ......, 15-22.

${ }^{7}$ Muhammad Salam Madkur, Al-Qadâ fí al-Islâm, (t.tp: t.t.), 11.

8 Tengku Muhammad Hasbi Ash-Sidiqi, Peradilan Dan Hukum Acara Islam, (Semarang: PT. Pustaka Rizki Putera, 1997), cet. I, 29.
} 


\section{Dasar Hukum Kedudukan Hakim}

Sabda Rasullah 能.

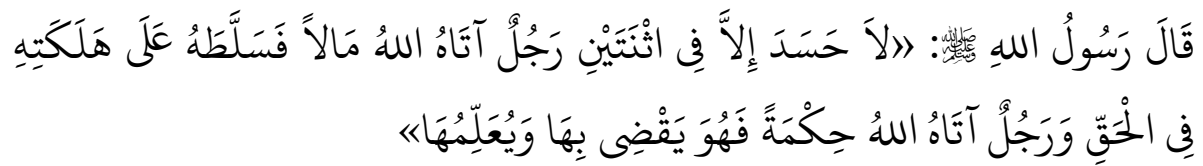

Artinya: "Tidaklah boleh dengki kecuali pada dua orang, pada seorang laki-laki yang di anugrabi Allah harta, lalu dia curabkan sampai habis membela kebenaran, dan pada seorang laki-laki yang di anugrabi Allah kebijaksanaan,lalu ia memutuskan perkara dan beramal dengan bijaksana."

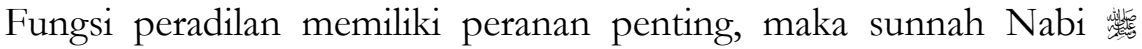
menampilkan hadist-hadist yang banyak yang memalingkan orang dari qadlẩ dan menjauhkan darinya, dengan tujuan menjauhkan orang yang menginginkan mencampuri urusan ini, padahal ia ahlinya, baik ia seorang alim yang menyeleweng atau seorang yang tidak memiliki kemampuan secara baik menerapkan keputusan-keputusan hukumnya atas kasuskasus yang terjadi, dan karena itu, di riwayatkan bahwa Rasulullah 咳 bersabda: ${ }^{10}$

القضاة ثلاثة: اقاضيان فى النار وقاض فى الجنة قاض عمل بالحق فق قضائه فهو فق الجنة وقاض علم الحق فق فجار متعمدا فدالك فى النار وقاض قضى يخير عالم واستحيا انيقول انى لا اعلم فهو فى النارش

Artinya: "Hakim-hakim itu terbagi itu (terbagi menjadi) tiga (golongan): yang dua (golongan) masuk surge, yang satu (golongan) berbuat adil dalam keputusan bukumnya,maka mereka masuk surga, yang satu (golongan) mengetahui keadilan itu tapi mereka menyelewengkan dengan sengaja, maka mereka masuk neraka, dan yang satu (golongan) memutuskan ( perkara) tanpa ilmu tetapi mereka malu mengatakan "aku tidak tabu" maka mereka (pun) masuk neraka".

Di riwayatkan oleh al-Nawâwî dalam kitabnya Nihâyat al-'Arab, Juz. VI, bahwa Sayyidah Aisyah berkata: Pernah mendengar Rasulullah 能: bersabda:

\footnotetext{
9 Muhammah Salam Mazkur, Peradilan dalam Islam, (Surabaya: PT. Bumi Ilmu Offece, t.t.), 4, 5 dan 6 .

10 Muhammah Salam Mazkur, Peradilan...., 76
} 


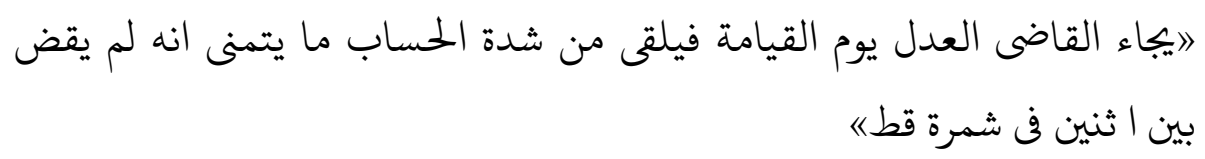

Artinya: "Pada hari kiamat nanti, qậdi (hakim) yang adil akan di bawa, kemudian ia terjatuh karena sangatnya pemeriksaan. Ia mengkhayal (alangkah baiknya kalua seandainya) ia tidak pernah memutuskan bukum di antara dua orang (yang berselisib) tentang sebiji buah sama sekali". ${ }^{11}$

\section{Kedudukan Hakim pada Pengadilan Agama}

Kedudukan hakim adalah sebagai pejabat yang melakukan kekuasaan kehakiman yang diatur dalam undang-undang. ${ }^{12}$ Kedududkan hakim juga di jelaskan pada UUD 1945 Pasal 24 ayat (2) yang menyatakan:

'Kekuasaan kehakiman dilakukan oleh sebuah Mahkamah Agung dan badan peradilan yang ada di bawahnya dalam lingkungan Peradilan Umum, lingkungan Peradilan Agama, lingkungan Peradilan Militer, Lingkungan Peradilan Tata Usaha Negara, dan oleh sebuah Mahkamah Konstitusi."

UU Nomor 7 Tahun 1989 Tentang Peradilan Agama sebagaimana telah diubah dan ditambah dengan UU Nomor 3 Tahun 2006 dan UU Nomor 50 Tahun 2009, Pasal 2 menyatakan:

'Peradilan Agama merupakan salah satu pelaksana kekuasaan kehakiman bagi rakyat pencari keadilan yang beragama Islam mengenai perkara perdata tertentu yang diatur dalam undang-undang ini."13

Pasal 3 UU Peradilan Agama tersebut menyatakan:

1. Kekuasaan kehakiman di lingkungan Peradilan Agama dilaksanakan oleh :
a. Pengadilan Agama
b. Pengadilan Tinggi Agama

2. Kekuasaan kehakiman di lingkungan Pengadilan Agama berpuncak pada Mahkamah Agung sebagai Pengadilan Negara Tertinggi.

Adapun kewajiban hakim menurut Undang-undang No. 4 Tahun 2004 sebagi pengganti UU No. 14 tahun 1970 adalah: ${ }^{14}$

a) Memutus demi keadilan berdasarkan Tuhan Yang Maha Esa.

\footnotetext{
${ }^{11}$ Muhammah Salam Mazkur, Peradilan....., 8-10

12 UU Nomor 3 Tahun 2006 dan UU Nomor 50 Tahun 2009

13 UU Nomor 3 Tahun 2006 dan UU Nomor 50 Tahun 2009..., 245

14 Undang-undang No. 4 Tahun 2004 sebagi Pengganti UU No. 14 tahun 1970
} 
b) Menggali, mengikuti, dan memahami nilai-nilai hukum dan rasa keadilan yang hidup di dalam masyarakat.

c) Dalam mempertimbangkan berat ringannya hukuman hakim wajib memberhatikan pula sifat yang baik dan jahat dari terdakwa.

Dengan demikian hakim adalah melaksanakan semua tugas yang menjadi tanggung jawabnya untuk memberikan kepastian hukum semua perkara yang masuk, baik perkara tersebut telah di atur dalam undangundang maupun yang tidak terdapat dalam ketentuannya dan sebagai pejabat Negara yang di angkat oleh kepala Negara sebagai penegak hukum dan keadilan yang diharpkan dapat menyelesaikan permasalahan yang telah di embannya meneurut undang-undang yang berlaku. Hakim merupakan unsur utama di dalam pengadilan. ${ }^{15}$ Bahkan ia "identik" dengan pengadilan itu sendiri.

Menurut ketentuan pasal 13 ayat (1) UU Nomor 7 Tahun 1989, untuk dapat diangkat menjadi hakim pada pengadilan agama, seorang calon harus memenuhi syarat-syarat sebagai berikut:

1. Warga Negara Indonesia.

2. Beragama Islam.

3. Bertakwa Kepada Tuhan Yang Maha Esa.

4. Setia kepada Pancasila dan Undang Undang Dasar 1945.

5. Bukan bekas anggota organisasi terlarang Partai Komunis Indonesia, termasuk organisasi massanya atau bukan seorang yang terlibat langsung ataupun tak langsung dalam "Gerakan Kontra Revolusi G.30.S/PKI”, atau organisasi terlarang lainnya.

6. Pegawai Negeri. ${ }^{16}$

7. Sarjana syari'ah atau sarjana hukum yang menguasai hukum Islam.

8. Berumur serendah-rendahnya 25 (dua puluh lima) tahun.

9. Berwibawa, jujur, adil, dan berkelakuan tidak tercela.

Adapun tentang status kepegawaian hakim, sesuai dengan diundangkannya UU No. 35 Tahun 1999 tentang perubahan terhadap UU No. 14 Tahun 1970 tentang Pokok-pokok Kekuasaan Kehakiman dan UU No. 43 Tahun 1999 tentang Perubahan Terhadap UU No. 8 Tahun 1974 tentang Pokok-pokok Kepegawaian, maka Korps kehakiman diberikan kewenangan untuk mengelola organisasi, administrasi dan keuangan badan pengadilan (termasuk pembinaan SDM hakim), yang tadinya di bawah kewenangan Departemen kepada

15 Cik Hasan Bisri, Peradilan Agama di Indonesia, Jakarta: PT. Raja Grafindo Persada, 1998), Cet. II, 180.

${ }^{16}$ Menurut Ketentuan Pasal 13 Ayat (1) UU Nomor 7 Tahun 1989. 
Mahkamah Agung. ${ }^{17}$ Peraturan ini juga masih tetap berlaku dalam UU No. 4 Tahun 2004 pada pasal 13 ayat (1) sebagai perubahan atas UU No. 35 Tahun 1999 tentang Ketentuan-ketentuan Pokok Kekuasaan Kehakiman yang menyatakan bahwa organisasi, administrasi, dan finansial Mahkamah Agung dan badan peradilan yang berada di bawahnya berada di bawah kekuasaan Mahkamah Agung, dan ayat (3) yang menyatakan ketentuan mengenai organisasi, administrasi, dan finansial badan peradilan sebagaimana dimaksud pada ayat (1) untuk masaing-masing lingkungan peradilan diatur dalam undang-undang sesuai dengan kekhususan lingkungan peradilan masing-masing. ${ }^{18}$ Dan perubahan status kepegawaian hakim pengadilan tingkat pertama dan tingkat banding, dari pegawai negeri sipil (PNS) menjadi pejabat negara. ${ }^{19}$

Undang-undang NO. 3/ 2006. Di dalam ketentuan pasal 49 di nyatakan:

"Pengadilan Agama bertugas dan berwewenang memeriksa, memutuskan dan menyelesaikan di tingkat pertama antara orang-orang yang beragama islam di bidang: 1) Perkawinan, 2) Waris, 3) Wasiat, 4) Hibah, 5) Wakaf, 6) Zakat, 7) Infaq, 8) Shadaqah, dan 9) Ekonomi Syari'ah."

\section{Pengertian Peradilan}

Peradilan menurut bahasa adalah segala sesuatu yang mengenai perkara pengadilan, para ahli hukum memberikan pengertian yang bermacam -macam namun dapat di simpulkan bahwa peradilan adalah kewenangan suatu lembaga untuk menyelesaikan perkara untuk atas nama hukum demi tegaknya hukum dan keadilan atau suatu peroses yang berakhir dengan memberikan suatu keputusan dengan tata cara tertentu yang di atur dengan peraturan hukum acara.$^{20}$

Menurut kamus bahasa Indonesia peradilan berarti: segala sesuatu mengenai perkara pengadilan. Lebih jelasnya Sudikno Mertokusumo menjelaskan bahwa: pengadilan di sini bukanlah di artikan semata-mata sebagai badan untuk mengadili, melainkan sebagai pengertian yang absrak, yaitu "hal memberikan keadilan", yaitu memberikan kepada yang bersangkutan kongritnya kepada yang mohon keadilan apa yang menjadi hak atau apa hukumnya.

\footnotetext{
17 Pasal 11 UU No. 35 Tahun 1999, dikutip dalam Kertas Kerja "Pembaruan Sistem Pembinaan SDM Hakim”, (Mahkamah Agung Republik Indonesia, 2003), 23.

18 UU No. 4 Tahun 2004 tentang Kekuasaan Kehakiman, (Surabaya: Karina, 2004), 3

19 Pasal 11 UU No. 43 Tahun 1999.

20 Adullah Tri Wahyudi, Peradialn Agama di idonesia, (Yogyakarta: Pustaka Pelajar, 2004), 01
} 
Ada beberapa unsur yang terkandung dalam rumusan pengertian peradilan dalam undang-undang No 4 tahun 2004 pasal 1 dan 2, yaitu : ${ }^{21}$

a) Peradilan merupakan suatu sistem atau proses penegakan hukum dan keadilan. Penegakan hukum dan keadilan tersebut di dasarkan kepada pencasila sebagai dasar negara. Artinya pelaksanaan peradilan tersenut harus sesuai nilai-nilai yang di dalam sila-sila pancasila dan tidak boleh bertentangan dengannya.

b) Di samping itu penyelenggaraan peradialan itu adalah dalam rangka terselenggaranya negara hukum republik indonesia.

c) Pengertian peradilan sebagaimana di kemukakan di atas juga membatasi bahwa hanya penegakan hukum dan keadilan melalui badan peradilan saja yang dikatakan sebagai peradilan. Sedangkan penegakan hukum dan keadilan oleh badan-badan lainnya seperti kepolisian kejaksaan dan lain-lain tidak tersebut sebagai peradilan.

\section{Dasar Hukum Keberadaan Peradilan Di Indonesia}

1. Undang-undang

Pasal 24 ayat 2 Undang-Undang 1945 menyebutkan bahwa kekuasaan kehakiman di lakukan oleh sebuah Mahkamah Agung dan peradilan yang berada di bawahnya dalam lingkungan peradilan umum, peradilan agama, lingkungan peradilan meliter, lingkungan peradilan tata usaha negara dan oleh sebuah Mahkamah Konstitusi. Undang-undang No 14 Tahun 1970 tentang ketentuan-ketentuan pokok kekuasaan kehakiman dalam pasal 10 ayat 1 menyebutkan: Kekuasaan kehakiman di lakukamn oleh pengadilan dalam lingkupan:

a) Peradilan umum

b) Peradilan agama

c) Peradilan meliter

d) Peradilan tata usaha negara

Undang-Undang No 14 Tahun 1970 ini telah di ubah dengan Undang-Undang No 35 Tahun 1999 dan terakhir diubah kedalam Undang-ndang No 5 Tahun 2009 tentang kekuasaan kehakiman pasal 10 ayat 1 dan 2 juga menjelaskan hal yang serupa dengan yang di atas, yaitu:

a) Kekuasaan kehakiman di lakukan oleh sebuah mahkamah agung dan peradilan yang ada dibawahnya dan oleh sebuah mahkamah konstitusi.

${ }^{21}$ UU No. 4 Tahun 2004 tentang Kekuasaan Kehakiman, (Surabaya: Karina, 2004) 
b) Badan peradilan yang berada di bawah mahkamah agung meliputi badan peradilan dalam lingkungan peradilan umum, peradilan agama, peradilan militer,dan peradilan tatausaha negara.

\section{Peradilan Agama di Indonesia}

Peradilan Agama merupakan salah satu dari empat lingkungan peradilan yang di sebut dalam pasal 10 UU.14/1970, yaitu undangundang tentang kekuasaa kehakiman.

Dapat kita ketahuai bahwa secara kelembagaan, substansi, kultural lembaga peradilan agama dapat di sebut sebagai peradilan islam. Hukum yang ditegakkan adalah hukum Islam yang bersumber pada al-qur'an, alhadist, ijma' dan al-ra'yu yang sudah di sistematis oleh manusia oleh kekuasaan negara.

Menurut Cik Hasan Bisri, ${ }^{22}$ untuk menjawab apakah lembaga peradilan agama di Indonesia apakah sama dengan lembaga peradilan islam (al-qadâ' fì al-Islâm), maka perlu di butuhkan landasan yang logis dan tunjanga oleh data empiris, secara sederhan ada beberapa landsan yang dapat di gunakan dalam mengidentifikasikan peradilan agama sebagai peradilan islam, yaitu Pertama: landasan teologis yang mengacu pada kekuasaan dan kehendak Allah yang berkenaan dengan penegakkan hukum dan keadilan. Kedua: landasan historis yang menghubungkan mata rantai peradilan agama dengan peradilan islam, yang menurut pendapat fuqaha' dan pakar hukum islam, tumbuh dan berkembang sejak masa Rasulullah. Ketiga: landasan yuridis yang mrngacu pada dan konsistan dengan konstitusi dan peraturan undang-undangan yang berlaku di negara republik Indonesia. Keempat. landasan sosiologi yang menunjukan bahwa peradilan agama merupakan peroduk interaksi antara elita islam the strategic elite dengan elit nasional lainya, terutama penguasa the ruling elite.

Dalam Undang -Undang NO 7 Tahun 1989 tentang peradilan agama secara garis besar dapat di ketahuai persamaan peradilan agama dengan peradilan islam, antara lain Pertama; peradilan agama adalah salah satu pelaksanaan kekuasaan kehakiman bagi rakyat para pencari keadilan yang beragamaislam mengenai perkara perdata tertentu. Kedua; Peradilan agama merupakan pengadilan yang memeriksa, pengdilan yang menyelesaikan perkara antara orang-orang yang beragama islam dalam

22 Cik Hasan Bisri, Peradilan Islam dan Tatanan Masyarakat Indonesian, (Bandung: PT. Remaja Rosdakarya, 1997), 40-43. Lihat Abdul Hakim, Pengertian Agama dalam Politik Hukum di Indonesia, (Jakarta: PT. Raja Grafindo Persada, 2000), 14-15. 
bidang perkawinan, kewarisan, hibab, wakaf, sedekah berdasarkan hukum islam. Ketiga; hukum-hukum yang di gunakan untuk mengadili dan memeutuskan perkara adalah hukum islam yang di buat berdasarkan campur tangan negara. Keempat, putusan lembaga peradilan wajib mencantumkan lafat "bismillâbirrabmânirrabîm" dan "Demi Keadilan Berdasarkan Ketuhanan Yang Maha Esa". Kelima; peradilan agama dapat memberikan keterangan pertimbangan dan nasib tentang masalah hukum islam kepada lembaga negara atau pemerintah apabila di minta. Keenam; hakim yang bekerja di lingkungan lembaga peradilan agama harus beragama islam dan di angkat oleh kepala negara dengan syarat-syarat dan prosedur yang telah di tentukan. Ketujub; hakim wajib mangadili, mengikuti, dan mememahami nilai-nilai hukum yang hidup dalam masyarakat. $^{23}$

\section{Tugas Hakim Pengadilan Agama}

Dalam menjalankan tugasnya, hakim memiliki kebebasan untuk membuat keputusan terlepas dari pengaruh pemerintah dan pengaruh lainnya. ia menjadi tumpuan dan harapan bagi pencari keadilan. Disamping itu mempunyai kewajiban ganda, disatu pihak merupakan pejabat yang di tugasi menerapkan hukum (i.̨âr al-bukm) terhadap perkara yang kongkrit baik terhadap hukum tertulis maupun tidak tertulis, dilain pihak sebagai penegak hukum dan keadilan di tuntut untuk dapat menggali, memahami, nilai-nilai yang ada dalam masyarakat. Secara makro di tuntut untuk memahami rasa hukum yang hidup di dalam masyarakat. ${ }^{24}$ Dengan demikian tugas hakim adalah melaksanakan semua tugas yang menjadi tanggung jawabnya untuk memberikan kepastian hukum semua perkara yang masuk baik perkara tersebut telah di atur dalam Undang-undang maupun yang tidak terdapat ketentuannya. Mencatat dan meneliti berkas perkara yang di terima, menentukan hari sidang, menyidangkan perkara, membuat keputusan/penetapan, mengevalusi dan menyelesaikan perkara yang ditangani serta melaksanakan tugas khusus dan melaporkan pelaksanaan tugas kepada Ketua Pengadilan Agama.

Dalam peradilan, tugas hakim adalah mempertahankan tata hukum, menetapkan apa yang ditentukan oleh hukum dalam suatu perkara.

23 Abdul Manan, Etika Hakim dalam Penyelenggaraan Peradilan, (Jakarta: Kencana, 2010), 257.

${ }^{24}$ Muhammad Salam Mazkur, Peradilan Dalam Islam, (Surabaya: PT. Bumi Ilmu Offece, t.t.), 2-3. 
Dengan demikian yang menjadi tugas pokoknya adalah menerima, memeriksa, dan mengadili serta menyelasaikan setiap perkara yang diajukan kepadanya.

Untuk mengatasi dari banyaknya masalah yang ada, hakim tidak perlu untuk selalu berpegang pada peraturan-peraturan yang tertulis saja. untuk mengatasi masalah tersebut hakim dapat menyelesaikannya dengan memperhatikan hukum yang hidup dalam masyarakat atau yang di kenal dengan hukum adat tidak semuanya ada peraturan perundangundangannya yang mengatur masalah tersebut. Sehingga dengan demikian tidak akan timbul istilah yang di kenal dengan sebutan kekosongan hukum. Kewenangan hakim untuk melakukan hal demikian ini sesuai pula dengan apa yang telah di tentukan dalam pasal 16 ayat (1) UU No. 4 Tahun 2004. ${ }^{25}$

Dengan melihat kenyataan di atas, maka tampak jelas bahwa dalam hal ini hakim harus aktif dari permulaan sampai akhir proses, Sedangkan setelah proses berakhir, hakim memimpin eksekusi.

Selain bersifat aktif, hakim bersifat pula pasif, Tugas Hakim hanya membantu para pencari keadilan dan mengatasi segala hambatan dan rintangan untuk dapat tercapainya keadilan. Dengan demikian tugas hakim tidak menentukan luas dari pokok sengketa, yang berarti hakim tidak boleh menambah atau menguranginya. ${ }^{26}$

"Tugas hakim pengadilan agama di dalam mewujudkan keadilan berdasarkan Ketuhanan Yang Maha Esa, bukan sekedar berperan memantapkan kepastian hukum, melainkan juga keadilan."27

Dalam penjelasan atas Undang-undang No. 4 Tahun 2004 tentang Kekuasaan Kehakiman Pasal 1, di jelaskan:

"Kebebasan dalam melaksanakan wewenang yudisial bersifat tidak mutlak karena tugas hakim adalah untuk menegakkan hukum dan keadilan berdasarkan Pancasila, sehingga putusannya mencerminkan rasa keadilan rakyat Indonesia."

Di samping yang lahiriyah, terdapat tanggung jawab hakim yang bersifat batiniah, yaitu:

${ }^{25}$ Deden Efendi, Kompleksitas Hakim Agama, (Jakarta: Dirjen Pembinaan Kelembagaan Agama Islam, 1985), 137.

26 Deden Efendi, Kompleksitas...., 141.

${ }^{27} \mathrm{Hal}$ ini secara resmi tercantum dalam Pasal 4 Ayat (1) UU No. 4 Tahun 2004 tentang Ketentuan-ketentuan Pokok Kekuasaan Kehakiman: "Demi keadilan berdasarkan Ketuhanan Yang Maba Esa”. 
"Bahwa karena sumpah jabatannya, dia tidak hanya bertanggung jawab pada hukum, kepada diri sendiri, dan kepada rakyat, tetapi bertanggung jawab kepada Tuhan Yang Maha Esa, yang dalam Undang-undang ini dirumuskan dengan ketentuan bahwa pengadilan dilakukan, 'Demi keadilan berdasarkan Ketuhanan Yang Maha Esa'. ${ }^{28}$

\section{Fungsi Hakim Pengadilan Agama}

Fungsi hakim adalah menegakkan kebenaran sesungguhnya dari apa yang di kemukakan dan dituntut oleh para pihak tanpa melebihi atau menguranginya terutama yang berkaitan dengan perkara perdata, sedangkan dalam perkara pidana mencari kebenaran sesungguhnya secara mutlak tidak terbatas pada apa yang telah di lakukan oleh terdakwa, ${ }^{29}$ melainkan dari itu harus di selidiki dari latar belakang perbuatan terdakwa.

Adapun kewajiban hakim menurut Undang-undang No. 48 Tahun 2009 sebagi pengganti UU No. 14 tahun 1970 adalah:

1. Memutus demi keadilan berdasarkan Tuhan Yang Maha Esa.

2. Menggali, mengikuti, dan memahami nilai-nilai hukum dan rasa keadilan yang hidup di dalam masyarakat.

3. Dalam mempertimbangkan berat ringannya hukuman, hakim wajib memberhatikan pula sifat yang baik dan jahat dari terdakwa.

Dengan demikian tugas hakim adalah melaksanakan semua tugas yang menjadi tanggung jawabnya untuk memberikan kepastian hukum semua perkara yang masuk, baik perkara tersebut telah di atur dalam undangundang maupun yang tidak terdapat dalam ketentuannya.

28 Penjelasan UU No. 14 Tahun 1970, I Umum, Butir 6, Alinea Terakhir.

${ }^{29}$ Abdul Kadir Muhammad, Hukum Acara Perdata Indonesia, (Bandung: Citra ditya Bakti, 1992), 37. 


\section{Penutup}

Seorang Hakim Pengadilan Agama memiliki kewajiban melaksanakan semua tugas yang menjadi tanggung jawabnya untuk memberikan kepastian hukum semua perkara yang masuk baik perkara tersebut telah di atur dalam Undang-undang maupun yang tidak terdapat ketentuannya, inilah yang menjadikan hakim bukan hanya sebagai pelaksana undangundang dalam menegakkan hukum tetapi juga sebagai pemberi keadilan terhadap orang-orang yang mencari kepastian hukum.

Selain itu hakim juga memiliki hak untuk memutus perkara dengan melalui pertimbangan dan alasan serta bukti-bukti yang ada di dalam persidangan, walaupun keputusan itu bertentangan dengan hukum formil yang ada. 


\section{Daftar Pustaka}

Bisri, Cik Hasan. Peradilan Agama di Indonesia. Cet. II. Jakarta: PT Raja Grafindo Persada. 1998. - Peradilan Islam dan Tatanan Masyarakat Indonesia. Bandung: PT. Remaja Rosdakarya. 1997.

Effendi, Deden. Kompleksitas Hakim Pengadilan Agama. Jakarta: Departemen Agama R.I. 1985.

Hakim, Abdul. Pengertian Agam dalam Politik Hukum di Idonesia. Jakarta: PT. Raja Grafindo Persada. 2000.

Hasbi al-Sidiqi dan Tengku Muhammad. Peradilan Dan Hukum Acara Islam. Cet. I. Semarang: PT. Pustaka Rizki Putera. 1997.

Lev, Daniel S. Peradilan Agama di Indonesia: Studi tentang Landasan Politik Lembaga-Lembaga Hukum. Alih Bahasa; H. Zaini Ahmad Noeh. Jakarta: PT. Intermasa. 1980.

Madkur, Muhammad Salam. Al-Qadâ fí al-Islâm. ttp. tt. . Peradilan dalam Islam. Surabaya: PT. Bumi Ilmu Offece. tt.

Manan, Abdul. Etika Hakim dalam Penyelenggaraan Peradilan. Jakarta: Kencana. 2010.

Muhammad, Abdul Kadir. Hukum Acara Perdata Indonesia. Bandung: Citra Ditya Bakti. 1992.

Pasal 13 ayat (1) UU Nomor 7 Tahun 1989, Pasal 11 UU No. 35 Tahun 1999, dikutip dalam Kertas Kerja Pembaruan Sistem Pembinaan SDM Hakim. Mahkamah Agung Republik Indonesia. 2003.

Soekanto, Soerjono. Ilmu-ilmu Hukum dan Pembangunan Hukum. Analisis Pendidikan. No.02, Tahun ke-IV. 1983.

UU No. 4 Tahun 2004 tentang Kekuasaan Kehakiman. Surabaya: Karina. 2004.

Wahyudi, Abdullah Tri. Peradialn Agama di Idonesia. Yogyakarta: Pustaka Pelajar. 2004. 